\title{
Preimplantation genetic diagnosis (PGD) according to medical ethics and medical law
}

\author{
Tıp etiği ve tıp hukuku açısından preimplantasyon genetik tanı (PGT)
}

\author{
Emine Elif Vatanoğlu Lutz \\ Department of Medical History and Ethics, Faculty of Medicine, Yeditepe University, Istanbul, Turkey
}

\section{Abstract}

\begin{abstract}
Assisted reproductive techniques not only nourish great and sometimes illusive hopes of couples who yearn for babies, but also spark new debates by reversing opinions, beliefs and values. Applications made to infertility clinics are increasing due to the influences such as broadcasts made by the media concerning assisted reproductive techniques and other infertility treatments, increase in the knowledge that people have about these problems, late marriages and postponement of childbearing age owing to sociological changes. Pre-implantation genetic diagnosis (PGD) is a technique applied to couples who are known to carry genetic diseases or who have children with genetic diseases. This technique is conducted by doctors in Turkey for its important contribution to decreasing the risk of genetic diseases and in order to raise healthy generations. In this paper, the general ethical debates and the legal situation in Turkey will be discussed.

(J Turkish-German Gynecol Assoc 2012; 13: 50-5)
\end{abstract}

Key words: Preimplantation genetic diagnosis, artificial implantation, genetic diseases, medical ethics, medical law

Received: 24 August, 2011

Accepted: 28 October, 2011
Özet

Yardımcı üreme teknikleri, çocuk arzusu duyan çiftlerde büyük ve bazen aldatıcı da olabilen umutları beslemenin yanı sıra, düşünceleri, inançları ve değerleri alt üst ederek yeni tartışmalar yaratmıştır. Medyanın yardımcı üreme teknikleri ve diğer infertilite tedavileri ile ilgili yayınlar yapması, insanların bu sorunlarla ilgili bilgilerinin artmasl, sosyolojik değişiklikler nedeniyle geç evlenme ve çocuk doğurma yaşının ertelenmesi gibi nedenlerle infertilite kliniklerine başvurular artmıştır. Preimplantasyon genetik tanı (PGT), daha önce genetik bir hastalık taşıdığı bilinen çiftlerde, genetik hastalıklı çocuğu olan çiftlerde uygulanan bir tekniktir. Türkiye'de genetik hastalık riskinin düşürülmesi yönündeki çok önemli katkısı ve sağlıklı nesiller yetiştirilmesi amacıyla bu tekniğe izin verilmektedir. Bu yazıda konuyla ilgili etik tartışmalara ve tıp hukuku açısından Türkiye'deki yasal duruma değinilmiştir. (J Turkish-German Gynecol Assoc 2012; 13: 50-5)

Anahtar kelimeler: Preimplantasyon genetik tanı, yapay döllenme, genetik hastalıklar, tıp etiği, tıp hukuku

Geliş Tarihi: 24 Ağustos 2011

Kabul Tarihi: 28 Ekim 2011

\section{Introduction}

Assisted reproductive techniques not only nourish great and sometimes illusive hopes of couples who yearn for babies, but also spark new debates by reversing opinions, beliefs and values. Applications made to infertility clinics are increasing due to influences such as broadcasts made by the media concerning assisted reproductive techniques and other infertility treatments, increase in the knowledge that people have about these problems, late marriages and postponement of childbearing age owing to sociological changes.

Many new problems have arisen and await solutions in this field in the context of donors, recipients, babies to be born and healthcare professionals.

While debates in this regard focus especially on the fundamental rights of individuals in European countries; this subject has also begun to become a current issue in our country after the inclusion of in vitro fertilization treatment in the scope of compulsory health expenditures.

Although in vitro fertilisation (IVF) with the husband's sperm is considered reasonable for married couples in many soci- eties and is included in the scope of compulsory insurance; in vitro fertilisation by a donor and its various methods give rise to many arguments. Fertilisation with medical assistance created different types of motherhood and fatherhood, and children who are the products of science, by separating sexuality from reproduction, selecting the embryos without any genetic diseases, conception from bloodline and biological affinity from emotions and nourishment. In addition to questions such as, "Who are the mother and father? What does parenthood mean?", problems arising from the lack of commercial and ethical standards, which require large amounts of money and significant inequalities, have sparked great debates in academies, courts, the media and public (1).

When we look at the development of assisted reproductive techniques, we realize that there is a substantial historical accumulation process in this field. Throughout the history, scientists looked for treatments and lenitives for infertility, which was a major fear, meanwhile quack doctors exploited the distress and desires of childless couples and earned a considerable amount of money. However in 1978, a miraculous development occurred; the first test tube baby, Louise Brown, was

Address for Correspondence: Emine Elif Vatanoğlu Lutz, Kayışdağ Cad. 26 Ağustos Yerleşimi, 34755 Kadıköy, İstanbul, Turkey

Phone: +9021657800 00-3087 e.mail: drvatanoglu@yahoo.com

(C) Copyright 2012 by the Turkish-German Gynecological Education and Research Foundation - Available online at www.jtgga.org doi:10.5152/jtgga.2011.72 
born in Manchester, England and brought fame to Dr. Edward. The method was successful for the first time, although considerable experimental accumulation on assisted reproduction treatment was behind it. The first experiment was conducted in 1791 by an English doctor named Hunter, and later a similar experiment was carried out in 1804 in France. The idea of donor artificial insemination (DAI) caused negative reactions from the very beginning and was disapproved by the Vatican. Nevertheless this method was conducted in 1884 for the first time in the USA by Dr. Pancost. Later, in 1940, Dr. Parker tried sperm cryopreservation techniques (2).

After this process of accumulation produced results in 1978, the first test tube baby Amandine was born in France and up to today thousands of babies were born through in vitro fertilization techniques. Dr. Carl Wood supervised the birth of the first cryopreserved embryo baby, Zoe, in 1984 in Melbourne. Doctors in the Netherlands and Britain followed his method and the rate of medical and biological development increased (3).

\section{Reproductive technology and major problematical areas} With every new medical or biological development, new problems arise. Concerning the arguments on reproductive technology, the status of the child and a specific family structure are the vital elements. In the Western world, in addition to the subjects of debate such as 'the right to have a child' or 'rights of the child'; subjects such as 'surrogate motherhood', 'insemination after death' or 'impregnation with sperm donation' have also gained importance today and legal arrangements have been made in many European countries and in the USA in this respect. Within a few years, tens of thousands of pregnancies have taken place through donor in vitro fertilisation, Egg and Sperm Research and Protection centers have been established and laws and regulations have been passed (4).

These techniques have been particular concerns not only to the persons that wished to take advantage of them but also to the child and the society in which the child would grow up. Problems regarding this matter have been not only technical but also extremely conceptual; legal and ethical aspects of this matter have been discussed under several titles, such as the naturality/artificiality of assisted reproductive techniques, moral and ethical position of human pre-embryo, role of the family and genetic link problem, rights of sperm/gamete donors and surrogate mothers and gender selection (5).

\section{Right to have a child and rights of the child}

The desire to have a child is a complicated need concerning the self-identity of an individual, nature of parenthood and his/her idea of family structure. The right to benefit from scientific developments in order to have a child due to this need is considered as a responsibility of governments and has been discussed in recent years not only in terms of reproductive rights, but also the assurance and subsidization of reproduction by medical science and the state. However, reproduction also has social and symbolic functions that imply familial and ethical references. No cultures can degrade bloodline to birth, motherhood to pregnancy or rights of the child to the desires of parents (4).
Although there are more problematic fields for donor artificial insemination, in which a third party is included in the process, operations between married couples, which gained general acceptance in many countries, are not free of problems. As methods of embryo cryopreservation develop, discussions have been initiated concerning the rights of the embryo.

While these developments were emerging, ethical disagreements were inevitable; the problem was not only the simplification of reproduction, it was about turning reproduction into a matter of choice; life could be deposited in the bank like an investment. It was also possible to make choices about the number of transplantations; and second twins were born in Melbourne 16 months after the birth of the first twins. The family tree of these children revealed results which were startling to some people; some dramatic results caused new polemics concerning multiple pregnancies and their family lives. Everything seemed possible; embryos could be manipulated and unused embryos could be used for in vitro fertilization experiments. The argument passed to the problem of the moment when an individual was created as a human being. In other words, what was the status of the embryo? (3)

There is no clear statement regarding the legal status of an unborn human being in the European Convention of Human Rights. Similarly, the Turkish Constitution (1982) does not cover a clear provision concerning this matter (6).

\section{Legal situation in Turkey}

Remarkable information regarding the approach to the fertilized human egg in the Turkish law is found in the Civil Code, Population Planning Law, its relevant legal arrangements and the Penal Code. Such arrangements do not accept an unborn human being as an individual. However, again in the framework of this legal arrangement, an unborn human being is provided with a limited protection. For instance, intentional abortion after the $10^{\text {th }}$ week of pregnancy, an abortion induced by some other person, although the mother's consent is given, has been defined as a crime in the Penal Code. The Civil Code also includes a provision that states that a fetus holds rights during the period when it is present in the mother's uterus until its live birth. When the legal qualification of the fertilized human egg after it leaves the uterus is evaluated, provisions which imply the non-acceptance of a person's existence are worthy of attention in the legal arrangements.

Concerning the embryos outside of uterus, provisions are made in the Regulation of Assisted-Reproduction Treatment Centers. This regulation indicates that embryos which are not used/cannot be used/are not agreed to be used by the applicants they are taken from need to be disposed of according to a specific procedure. It is clear here that the embryo is not protected by a right to live. It is clearly stated in the Regulation of AssistedReproduction Treatment Centers that unwanted embryos cannot be used for any other purposes except for assisted-reproduction treatment method (6).

Although "Protection of Human Rights and Human Dignity in Terms of Biology and Medical Practices, Human Rights and Biomedicine Agreement" (Biomedicine Agreement) does not 
prohibit research to be conducted on an embryo in a tube, it specifies that, in the event that it is allowed by the laws, adequate protection needs to be provided for the embryo. However, the Agreement also indicates that researches need to be conducted within the framework of the laws. A legal arrangement regarding this matter does not exist in Turkey. Our country is in need of a legal arrangement in this respect.

Creation of an embryo for the purpose of research has been prohibited in the Biomedicine Agreement. Accordingly, creation of an embryo with the sole purpose of research is not possible in Turkey. Contrary acts cause contradiction with the Biomedicine Agreement (6).

The Biomedicine Agreement signed by Turkey on April $4^{\text {th }}, 1997$, has been approved by the Turkish Grand National Assembly on 3.12.2003 and the relevant law has entered into force on the same date with the name, "Protection of Human Rights and Human Dignity Agreement in Terms of Biology and Medical Practices: Law Concerning Approval of Human Rights and Biomedicine Agreement" after having been published on the Official Gazette numbered 25311 on December $9^{\text {th }}, 2003$ with the Law number 5013 (6).

In terms of the Turkish judicial system, the place of international agreements within municipal law is determined by the $90^{\text {th }}$ article of the Constitution. According to this article; "Approval of agreements to be made with foreign states and international organizations on behalf of the Republic of Turkey is subject to the confirmation of the Turkish Grand National Assembly through a law". In the continuation of this article, it is specified that international agreements put into force in due form are statutory and lawsuits cannot be brought against them with a plea of unconstitutionality. On the other hand, with an addition made to the $90^{\text {th }}$ article of the Constitution on 7.5.2004 through law no. 5170, it is stated that, in the case of a contradiction arising due to different provisions taking place in international agreements and laws concerning fundamental rights and freedoms, provisions of international agreements shall be the basis. "Human Rights and Biomedicine Agreement", which is a part of Turkish municipal law, sets an example for such international documents (6).

\section{Preimplantation genetic diagnosis according to medical law}

In this context, the most controversial subjects regarding the usage of assisted reproductive techniques can be specified as: who can be sperm donors, if the set criteria are reliable in terms of genetics and biology, if the criteria are reliable in terms of health or aesthetic and social terms, whose sperm shall be used to fertilize, whose consent shall be obtained, if the sperm donor holds a right of fatherhood, if this right can be taken from this person and if so, who shall remove this right, how the selling of sperm and therefore commercialization shall be prevented, if the surrogate mother or the biological mother holds rights on the child; when embryos are created with more than one gamete for in vitro fertilization practices and one or more embryo(s) is/are placed in the mother's uterus, what shall happen to the other embryos, if they shall be disposed of or why, how and for what purpose they shall be kept. These problems form the most significant and current central points of legal arguments in this field, as shall be discussed here (7).
First of all, assisted-reproduction tools and methods must be arranged in accordance with the laws in our country. Legal loopholes create serious problems and misappropriation not only in penal law but also in private law. In fact, we cannot take action according to an assumption/postulate that anything we are able to do as human beings is allowed (7).

Apart from a Law Concerning Protection of Embryo, a Law Concerning Stem Cell Studies, a Law Concerning Protection of Personal Data, a Data Bank Law generally known as the conception of DNA Bank in our country which has got a limited meaning and a Bio-bank Law need to be legislated.

Lack of legal arrangements and punishment norms, especially in terms of serious violations, will also open the doors for other negative results: Just as individuals can perform the acts that are prohibited by Turkish regulations in North Cyprus, Greece or Belgium and avoid their responsibilities in Turkey, Turkey may become a paradise of experimental acts on embryos in the event that a legal arrangement is not made; Turkey may be deemed to have helped since it shall not inflict punishments on such acts, may be deemed not to have done her part in terms of international law and not to have performed the liabilities imposed by the international agreements. Persons visiting Turkey may conduct acts on embryos such as experiments, heterologous insemination, surrogate motherhood, fertilizing human eggs or sperms with the dead or animals or other acts that we examine within this study (6).

Since the decision made by the High Council of Health in 1987 regarding the approval of in vitro fertilization practices, the allowed acts in Turkey are; the limited permission of such acts and allowing them in the institutions and organizations approved by the Ministry of Health under control/supervision, in a very limited area.

Laws have not yet been legislated and this subject is managed through legislations, memorandums and regulations. Considering positive texts, "In Vitro Fertilization and Embryo Transfer Centers Regulation" has been published by the Ministry of Public Health and Welfare for the first time in 1987 and first practices started after this date. This regulation has been changed many times and it has been renamed "AssistedReproduction Treatment Centers Regulation" as it is presently called. This lack of law causes many misappropriations and legal loopholes, prevents the punishment of offenders and leads to the limitation of the rights and freedoms of individuals arbitrarily through legislations or memorandums/regulations; which contradict the $13^{\text {th }}$ article of the Constitution that requires limitations not to affect the rights and freedoms and to be in accordance with the relevant laws (implicitly, also with the international laws when the $90^{\text {th }}$ article of the Constitution is taken into consideration) (6).

According to the practices conducted since 1987 under the control of the Ministry of Health; in case the mother is infertile, fertilizing the mother's egg with the father's sperm in a tube and placing it in the mother's uterus is allowed, only for married couples and with the couple's eggs and sperms. Although lacking legal grounds, deontologists who mistake the law for customs and traditions or; morals for law, describe the artifi- 
cial insemination made with eggs or sperms taken from other people as 'illegal' faultily, without any exceptions and any legal grounds. In addition to such justifications, there are concerns regarding the possibilities such as, the mother or father may claim rights to the child afterwards, the child may have negative feelings towards his/her mother and/or father, possible marriages between brothers and sisters or between the children and the parents. However, even those who object to such opinions acknowledge that these problems can be solved in a modern society in legal and ethical terms, cannot bring forward their arguments about contradiction with ethics and law; and close the doors of opposition to such methods (6).

According to the Regulation (Assisted-Reproduction Treatment Centers Regulation), assisted-reproduction centers require the couples to be married, to use only their own germ cells and cannot have children through the current treatment methods stipulated in the Regulation for married couples. There are no positive texts arranging the legal status for people except for the aforementioned couples (6).

As we know, preimplantation genetic diagnosis allows the genetic characteristics of embryos to be studied before being transferred to the uterus to prevent the birth of a child with genetic defects in couples with high genetic risk. This technique is useful in couples who have a high risk of passing on certain genetic diseases or chromosome mutations to their children. It is also indicated in some couples coming from an IVF programme.

Monogenic diseases are those caused by a specific gene mutation (cystic fibrosis, thalassemias, fragile $\mathrm{X}$ syndrome, etc.). To prevent the transmission of this disease by use of PGD, it is essential to know the mutation causing the disease.

If a family has a disease associated with $\mathrm{X}$ chromosome but the specific gene alteration is not known, PGD can be conducted by means of gender selection. Gender selection for social reasons is prohibited.

The presence of a chromosome reorganisation (Robertsonian translocations, reciprocal translocations and inversions) in one member of the couple may lead to difficulties in conceiving, miscarriages or congenital malformations. The use of PGD in these couples is extremely useful (8).

It is also indicated in cases of numerical chromosome abnormalities, pure or mosaic.

Both in the case of monogenic diseases and those associated with chromosomal reorganisation, it is necessary to conduct a genetic informativity study before the PGD cycle to confirm that the diagnosis is reliable and to adjust the technique to each individual case.

PGD permits the screening for chromosomes most commonly involved in prenatal abnormalities and miscarriages during the first trimester. The aim is to improve rates of live home births by means of increased implantation rates and a reduction in the number of miscarriages and conceptions with chromosomal diseases.This may be indicated in various situations such as; advanced maternal age ( $>37$ years), altered male meiosis, couples with repeated miscarriage and couples with repeated implantation failures (8).
It is known that mutations of some genes predispose individuals to certain diseases that may appear at different life stages, such as neurofibromatosis, familial adenomatous polyposis or genetic breast cancer (BRCA1, BRCA2), etc.

When a hereditary disease component is confirmed, the possibility of PGD would allow the possible appearance of this disease in the next generation to be avoided.

In order to apply the preimplantation genetic diagnosis (PGD), it is necessary to obtain embryos from the couple using IVF techniques, even when there are no infertility issues. Embryo biopsy is conducted three days after insemination, when the embryo has about 6-10 cells. It consists of extracting one or two cells from the embryo, but without affecting its normal development. Using a laser fitted to a microscope, the outer layer of the embryo (zona pellucida) is dissected and the biopsy is then performed. Once the biopsy has been performed, the embryo is maintained in culture until the time of transfer (day +5) (9). The biopsy obtained is then processed for analysis by means of Fluorescent In Situ Hybridization (FISH) or Polymerase Chain Reaction (PCR), depending on the disease being analysed. Cytogenetic analysis of interphase nuclei allows us to detect both numeric and structural chromosome mutations. The FISH technique consists of applying DNA probes which are specific for the chromosomes being analysed and this enables the chromosomes analysed to be counted, detecting possible aneuploidy (missing or extra chromosomes).

In the case of chromosome reorganisation, the chromosomes analysed are only those involved in the reorganisation. For aneuploidy screening in IVF patients, the 13, 15, 16, 18, 21, 22, X and $\mathrm{Y}$ chromosomes are studied, which permits a large number of abnormalities to be ruled out. The PCR technique is used for the diagnosis of monogenic diseases. With this process, the presence of the altered gene is detected using specific DNA sequence amplification. The diagnostic efficiency with the PGD technique is approximately $95 \%$ (9).

On the other hand, according to the latest contemporary experiments, Array-CGH will detect approximately 50\% more abnormalities than 12 probe FISH and 20\% more abnormal embryos (abnormalities tend to concentrate on the same embryos). Being quantitative, Array-CGH can detect all aneuploidies. It should be noted that Array-CGH cannot detect polyploidy, but this would result in only $0.2 \%$ missed abnormalities. Array CGH can detect deletions and duplications of small pieces of DNA. Presently, we are using Array-CGH not only to detect whole chromosome numerical abnormalities (aneuploidy) but also for translocations, inversions and other chromosomal abnormalities (10).

The choice of which embryos to transfer is based on the genetic test results and the embryonic viability characteristics. If there are extra viable pre-embryos which are not transferred in this cycle these are cryopreserved for subsequent cycles. After a PGD cycle, Prenatal Diagnostic testing is advisable during the first weeks of pregnancy (9).

Although preimplantation genetic diagnosis (PGD), makes a great contribution to the decrease of genetic disease risks, disposal of such embryos spark ethical and legal debates. In our country, a human being cannot be mentioned as long as a 
human-specific distinctive such as implantation and primitive band on the uterus wall becomes evident and diagnosed by scientists, and the $28^{\text {th }}$ article of Turkish Civil Code states that a human being cannot be mentioned as long as the fetus is born live from the uterus, penal law protection norms peculiar to human life cannot function here; this embryo is considered as a part of the human body and as a tissue within this period, it is only protected within the scope of the norms that protect human organs and tissues, in other words, the special law against trading of organs and tissues; and the articles 91-93 of Turkish Civil Code. However another opinion claims that human life starts with insemination; and when this opinion is accepted, existence of a human being shall be accepted immediately after the insemination process is completed and relevant norms shall be applied as an act has been conducted against an individual (11).

According to the Swiss Civil Code (art. 31), when a person is born live, legal protections regarding his/her life start at that moment. Although rights are accorded to the embryo, which holds a life capability, to be used after it is born, it is indirectly protected through penal law protection, regulations concerning crime types of abortion or miscarriage; and norms protecting the life and physical integrity of the mother. The actual direct protection starts when it is an individual, after its birth. Interventions on the physical integrity of the embryo are not considered as physical violence or abortion acts; there are no penal laws concerning such crimes. We see the same lack of protection in genetic manipulations conducted on the embryo. The embryo can even be taken from the mother's uterus with her consent until a certain period of time and the law does not impose any responsibility judgments on this act. Sex determination on the fetus is also an unpunished illegal act; and limitless permitted artificial insemination among unmarried couples will cause bloodline problems and ethical and legal problems such as parent-child or brother-sister marriages in the future. This subject needs to be juridically arranged (8).

Despite the prohibitory provisions of the Biomedicine Agreement (art. $11 \mathrm{vd}$, art. 13 and art. $15 \mathrm{vd}$ ) and without any technical differentiations, some writers argue that such researches should be permitted in our country on the condition that they shall not exceed 25 days after insemination. It must be noted that the $18^{\text {th }}$ article of the European Council Biomedicine Agreement is related especially to in vitro fertilization and according to the text within this article, in cases where the law allows researches to be conducted on the embryo, appropriate protection shall be provided for the embryo (paragraph: 1) and creation of human embryos only for research purposes is forbidden (paragraph: 2) (6).

\section{Ethical Conflicts}

In the case of preimplantation genetic diagnosis, healthy infants are chosen and this intervention is considered as ethical behavior and conducted by doctors in Turkey in order to raise healthy generations. Although it is stated with general expressions that 'if transmittance of the disease cannot be prevented even though all necessary precautions are taken, the operation must not be conducted', such diseases need to be interpreted as serious diseases that can leave the child disabled, irremediable diseases or genetically hereditary serious diseases (7).
However, due to the fact that these operations are not inspected as needed, such interventions are conducted with payment in order to fulfill the desire of the families that want to have male children, on women of advanced ages on whom assisted reproductive techniques have been conducted previously, on couples who are known to carry genetic diseases or who have children with genetic diseases, or for sex determination purposes (generally for a high payment).

Such interventions clearly contradict the $14^{\text {th }}$ article of the European Council Biomedicine Agreement (6).

During such operations, it is possible that embryos with unwanted genders are generally disposed of or used for illicit trade and sold to unmarried or other married couples (third persons) for artificial insemination. Such acts contradict the European Council Biomedicine Agreement, which was also signed and approved by Turkey. The Agreement allows such operations only in case of venereal diseases and prohibits them in any other cases. Since Turkey did not legislate a law as a sub-norm after signing the agreement, such interventions are not punished by penal law and are outside the enforcement-scope of protection (7).

Moreover, the opposite of such an intervention is also possible. For instance, it is possible for a handicapped - dwarf couple to use the method of embryo scanning and look for the embryo that will be a physically disabled child like them. In this example, we face a "handicapped baby order" instead of "perfect baby order". The desire to have a child like them, to lead an easier life with the baby and look after the baby effortlessly can make couples go to any extremes. This method, which has been developed for fighting against genetic diseases, intervened chromosomes due to the egoistic, unethical and illegal desires of parents and an 'order' has been given for a child that will spend his/her whole life as a disabled person. This incident occurred in Chicago in 2006, Cara and Gibson Relnolds from New Jersey, ordered a dwarf baby in a clinic through this embryo scanning method (Pre-implantation Genetic Diagnosis=PGD), which is normally used for diagnosing serious genetic diseases before the embryo is placed in the mother's uterus (12).

Some claim that such demands are numerous and they may be fulfilled in some clinics. Fundamentally, although these types of interventions are not for research purposes and have the characteristics of a known method or tool, such practices contradict $13^{\text {th }}$ article of European Council Biomedicine Agreement, which prohibits researches intended to change the genetic structure of human breeds, the $11^{\text {th }}$ article which prohibits discrimination and the $12^{\text {th }}$ article which specifies that genetic tests only need to be conducted for human health and treatment purposes (6). The $18^{\text {th }}$ article of the Biomedicine Agreement is related to researches to be conducted on embryos in tubes and states that provisions of law may allow researches to be conducted on embryos in tubes. In such cases, the embryo needs to be provided with the appropriate protection, but creation of embryos only for research purposes is prohibited. A similar regulation also takes place in the UNESCO Declaration and EU Charter of Fundamental Rights (7).

Medical interventions for sex determination are prohibited in Germany and are considered as a violation of human dignity in doctrine. 
Sex determination interventions on embryos are only allowed for gender-related genetic diseases; and even this provision, which is actually compatible with the European Council Biomedicine Agreement, has been criticized in the German doctrine due to its potential For misappropriation.

Medical interventions for sex determination are also prohibited in Britain, Spain and many other European countries (6).

\section{Conclusion}

Reproductive health is one of the most important elements of general health. Its effects can be seen and followed through generations in not only productive periods of life, but also in all stages of life, from newborn infancy to teenage, and from teenage to old-age.

Being able to control their own reproduction process as men and women, planning their fertility without risking their lives with effective, reliable, affordable and acceptable contraceptive methods, having safe pregnancies and giving safe births for women, having a live infant and providing the infant with the best possible health services for a healthy growth are the main purposes of health services.

Yet in the research conducted on embryos, it is not the embryo itself but others (its parents) who need to give consent, and the aforementioned research processes mean the end of the embryo's 'life'. This situation increases the importance of researcher responsibilities; if scientists give objective and fair information to adults who shall decide whether embryos will be volunteers/experimental subjects or embryos, they will increase the confidence placed in results and the support to be given in the public conscience.

For the present, it does not seem easy to reach a compromise which will not prevent the benefits of science to humanity, yet will enable individuals to make their own choices according to their beliefs and value judgement.

\section{Conflict of interest}

No conflict of interest was declared by the authors.

\section{References}

1. Lalioti MD. Preimplantation genetic diagnosis. Minerva Ginecol 2010; 62: 213-23.

2. Ehrich K, Williams C. A 'healthy baby': The double imperative of preimplantation genetic diagnosis. Health (London) 2010; 14: 41-56. [CrossRef]

3. Vollmann J., 'In Vitro Fertilisation', The Book of the Symposium on the Criminal Law, Ethical and Medical Problems in the Field of Pharmacy and Medicine (Illaç ve Tıp Alanında Ceza Hukuku, Etik ve Tibbi Sorunlar Sempozyumu Kitabı), İstanbul, October, 2008, p.7

4. Hershberger PE, Pierce PF. Conceptualizing couples' decision making in PGD: emerging cognitive, emotional, and moral dimensions. Patient Educ Couns 2010; 81: 53-62. [CrossRef]

5. Macklin R. The ethics of sex selection and family balancing. Journal Semin Reprod Med 2010; 28: 315-21. [CrossRef]

6. Ünver Y., 'Türkiye'de Ceza Hukuku Açısından Sun'i Döllenme' (In Vitro Fertilization According to Criminal Law in Turkey), The Book of the Symposium on the Criminal Law, Ethical and Medical Problems in the Field of Pharmacy and Medicine (Ilaç ve Tıp Alanında Ceza Hukuku, Etik ve Tibbi Sorunlar Sempozyumu Kitabı), October 2008, p.21

7. Ünver Y., 'Avrupa Biyo-Tıp Sözlesmesi'nin Türk Hukukuna Etkileri,' (The Effects of European Biomedicine Convention on Turkish Law), Archive of Public Law, İstanbul, November, 2005, p. 182.

8. Mastenbroek S, Twisk M, van Echten-Arends J, Sikkema-Raddatz B, Korevaar JC, Verhoeve HR, et al. In vitro fertilization with preimplantation genetic screening. N Engl J Med 2007; 357: 9-17. [CrossRef]

9. Staessen C, Platteau P, Van Assche E, Michiels A, Tournaye H, Camus M, et al. Comparison of blastocyst transfer with or without preimplantation genetic diagnosis for aneuploidy screening in couples with advanced maternal age: a prospective randomized controlled trial. Hum Reprod 2004; 19: 2849-58. [CrossRef]

10. Le Caignec C, Spits C, Sermon K, De Rycke M, Thienpont B, Debrock S, et al. Single-cell chromosomal imbalances detection by array CGH. Nucleic Acids Res 2006; 34: e68. [CrossRef]

11. Hakeri H, Ünver Y, Yenerer Çakmut Ö., 'Tıp/Sağlık Hukuku Mevzuatı', Seçkin Publishing House, Ankara, 2010 April, p. 727-50.

12. http://www.msnbc.msn.com/id/16299656/ns/health-pregnancy/t/ designer-babies-made-to-order-defects/ 